\title{
EVALUATION OF BONE MINERAL DENSITY USING CONE BEAM COMPUTED TOMOGRAPHY
}

\author{
Mohammad Sadegh Nazari ${ }^{1 a}$, Ahmad Reza Tallaeipoor ${ }^{2 b}$, Ludovica Nuccicc, Amir Ali Karamifar ${ }^{4 d}$, Abdolreza Jamilian ${ }^{5 \mathrm{e}^{*}}$ (D) , \\ Letizia Perillo ${ }^{3 f}$ (D)
}

\begin{abstract}
'Department of Orthodontics, School of dentistry, Mashhad University of Medical Sciences, Mashhad, Iran
2Department of Oral and Maxillofacial Radiology, Cranio Maxillofacial Research Center, Faculty of Dentistry, Tehran Medical Sciences, Islamic Azad University, Tehran, Iran

${ }^{3}$ Multidisciplinary Department of Medical-Surgical and Dental Specialties, Dental School, University of Campania Luigi Vanvitelli, Naples, Italy ${ }^{4}$ Department of Orthodontics, School of Dentistry, Semnan University of Medical Sciences, Semnan, Iran

5Department of Orthodontics, Cranio Maxillofacial Research Center, Faculty of Dentistry, Tehran Medical Sciences, Islamic Azad University, Tehran, Iran
\end{abstract}

\author{
aPostgraduate Dental Student \\ ${ }^{\mathrm{b}}$ DDS, PhD, Professor \\ 'Undergraduate Dental Student \\ ${ }^{\mathrm{D} D D S}, \mathrm{MSC}$ \\ ${ }^{e} D D S$, PhD, Professor \\ ${ }^{\mathrm{f} D D S}$, PhD, Professor
}

\section{ABSTRACT DOI: https://doi.org/10.25241/stomaeduj.2019.6(4).art.4}

Introduction: Bone mineral density (BMD) is an important factor in the use of anchorage device. This study assessed the amount of bone density in the areas from 2.5 and $8.11 \mathrm{~mm}$ from maxillary alveolar to basal bone in Hounsfield units. Methodology: The samples included 30 unilateral cleft palate (15 males and 15 females) with the mean age of $14.23 \pm 2.5$ years and 30 non-clefts ( 15 males and 15 females) with the mean age of $14 \pm 2.59$ years. CBCT was used to estimate the values of bone density in Hounsfield units in the cleft and noncleft patients. BMD was measured in 4 heights $(2-5-8-11 \mathrm{~mm})$ from alveolar bone to basal bone in mesio-distal and bucco-lingual slices in the upper jaw. T-test was used to analyze the bone density values between the cleft and noncleft.

Results: The highest alveolar bone density in the mesio-distal slice was 1004 $6 \mathrm{HU}$ between the right and left centrals in the upper jaw in height of $11 \mathrm{~mm}$ in non-cleft patients. The least amount of alveolar bone density in the mesio-distal slice was $259 \pm 29 \mathrm{HU}$ in tuberosity in height of $11 \mathrm{~mm}$ in cleft patients. In non-cleft patients, the most amount of bone density was found $1639 \pm 11 \mathrm{HU}$ between the centrals in height of $11 \mathrm{~mm}$ in the bucco-lingual slice.

Conclusions: Bone density in cleft patients was lower than in non-cleft patients in all areas and maxillary tuberosity showed the lowest bone density in cleft and non-cleft patients.

Keywords: Cone Beam Computed Tomography; Bone Mineral Density; Dental Implants; Single-Tooth; Orthodontics.

\section{Introduction}

The amount of bone tissue is called bone mineral density (BMD)[1]. Assessment of BMD is necessary in many clinical conditions such as oral systemic diseases, implant planning and it also has an important role for the stability of mini-implants as anchorage $[2,3]$. Computed tomography (CT) is a diagnostic method before performing dental implant. It allows accurate three-dimensional evaluation of anatomical structures of the bone. It also measures BMD which it expresses in Hounsfield units (HU) [4]. Although CT is a diagnostic tool in medical practice, this method has not been broadly used in dentistry because of its high cost, presence of artifacts in images, high dose of radiation and complexity of examination.

Recently CT has been replaced by cone-beam computed tomography (CBCT) to evaluate anatomic structuresand the directmeasurement ofmineralized tissue $[5,6]$. CBCT provides suitable image quality concomitant with a lower exposure dose. Fast scanning time, low cost and a lower number of image artifacts are the other advantages of CBCT when compared to CT [7-9]. CBCT scanning is associated with some drawbacks, such as poor soft tissue contrast, motion 

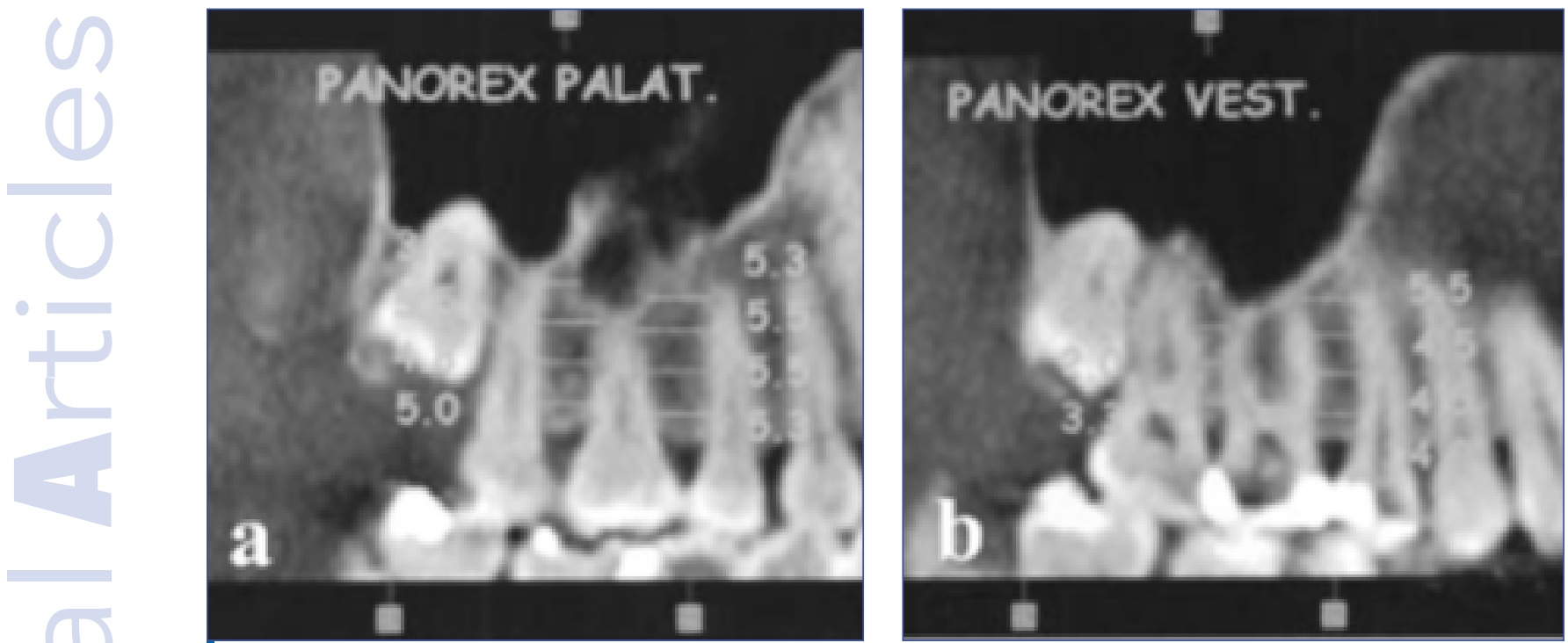

Figure 1. (a) Mesio-distal measurement on the palatal side; (b) Mesio-distal measurement on the buccal side
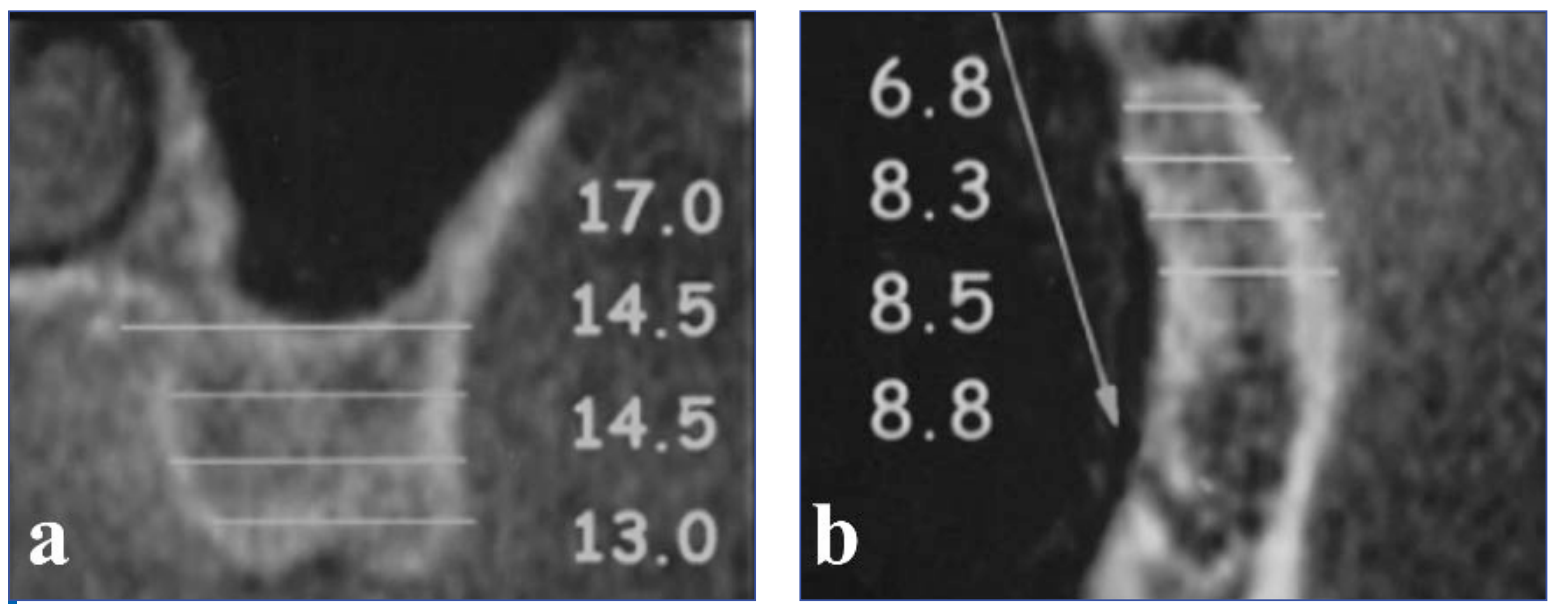

Figure 2. (a) Bucco-lingual measurement on the maxilla; (b) Bucco-lingual measurement on the mandible

artifacts and image noise. Conventional CT may distinguish $70 \%$ of root fractures, but the higher cost and high dose of radiation limit the use of this technique [10].

BMD can be recognized by Gray values acquired with $\mathrm{CBCT}$ as the $\mathrm{HU}$ values [11]. CBCT provides a three-dimensional analysis with the quantification of the mineral density of jaws in Hounsfield units (HU) [3].

CBCT is a valuable method for diagnosis and treatment planning especially in cleft lip and palate patients because it offers better data about the size and appearance of the anatomic structures affected by the cleft, the position of missing teeth, the amount of BMD, as well as the position of mini screw, dental implants and so on. To our knowledge no study compared the BMD of cleft patients with non-cleft samples.

Therefore, due to the lack of research in this area the aim of this study was to compare the BMD of interradicular distances at heights of 2, 5, 8 and $11 \mathrm{~mm}$ measured from the alveolar bone crest to basal bone in $\mathrm{HU}$ obtained by CBCT in unilateral cleft palate and non-cleft patients.

\section{Methodology}

This research protocol was approved by the Ethics Committee at the Islamic Azad University, Dental School, Protocol number 25500. The participants in this retrospective research were 30 unilateral cleft palates (15 males and 15 females) with the mean age of $14.23+2.5$ years and 30 non-cleft patients (15 males and 15 females) with the mean age of $14+2.59$ years. The criteria to select the patients were as follows: no history of serious disease affecting oral bones, no periodontal problems, no previous fracture, no history of bone grafting, no previous orthodontic therapy, none of the patients were on hormone therapy or taking calcium, vitamin $D$, fluorides, calcitonin, bisphosphonates, no palatal fistula or infection. CBCT of all the patients were taken by the same radiologist for orthodontic treatment. All unilateral cleft palate patients had palatal closure before the age of 2. The CBCT (New Tom 5G; QR, Verona, Italy) was performed to assess BMD in the cleft and noncleft regions in all patients. The images were obtained at $120 \mathrm{kV}$ and $8 \mathrm{~mA} .0 .2 \mathrm{~mm}^{3}$ voxel, $80 \mathrm{~mm}$ field of view BMD was calculated using the Xoran Cat software version 3.1.62 (Xoran Techno- 
Table 1. BMD in Hounsfield units (HU) from the mesio-distal slice in the maxillary arch between teeth and tuberosity.

\begin{tabular}{|c|c|c|c|c|c|}
\hline & Mesio-distal slice & $2 \mathrm{~mm}$ & $5 \mathrm{~mm}$ & $8 \mathrm{~mm}$ & $11 \mathrm{~mm}$ \\
\hline Region & Group & Mean \pm SD & Mean \pm SD & Mean \pm SD & Mean $\pm S D$ \\
\hline $1-1$ & $\begin{array}{c}\text { Non-cleft } \\
\text { Cleft }\end{array}$ & $\begin{array}{c}896 \pm 17^{* *} \\
884 \pm 5\end{array}$ & $\begin{array}{c}935 \pm 6 * * \\
923 \pm 7\end{array}$ & $\begin{array}{c}983 \pm 4^{* *} \\
973 \pm 5\end{array}$ & $\begin{array}{c}1004 \pm 6 * * \\
994 \pm 5\end{array}$ \\
\hline 2-1 & $\begin{array}{c}\text { Non-cleft } \\
\text { Cleft }\end{array}$ & $\begin{array}{c}874 \pm 7^{* *} \\
862 \pm 9\end{array}$ & $\begin{array}{c}916 \pm 5^{* *} \\
908 \pm 8\end{array}$ & $\begin{array}{c}953 \pm 6^{* *} \\
941 \pm 8\end{array}$ & $\begin{array}{c}994 \pm 5^{* *} \\
984 \pm 6\end{array}$ \\
\hline $3-2$ & $\begin{array}{c}\text { Non-cleft } \\
\text { Cleft }\end{array}$ & $\begin{array}{c}851 \pm 6 * * \\
842 \pm 19\end{array}$ & $\begin{array}{c}897 \pm 25 * \\
882 \pm 27\end{array}$ & $\begin{array}{c}935 \pm 77^{* *} \\
923 \pm 9\end{array}$ & $\begin{array}{c}945 \pm 5 * * \\
932 \pm 10\end{array}$ \\
\hline 4-3 & $\begin{array}{c}\text { Non-cleft } \\
\text { Cleft }\end{array}$ & $\begin{array}{c}845 \pm 25 * \\
832 \pm 26\end{array}$ & $\begin{array}{l}872 \pm 28 \\
860 \pm 29\end{array}$ & $\begin{array}{l}896 \pm 27 \\
885 \pm 27\end{array}$ & $\begin{array}{l}915 \pm 34 \\
904 \pm 34\end{array}$ \\
\hline $5-4$ & $\begin{array}{c}\text { Non-cleft } \\
\text { Cleft }\end{array}$ & $\begin{array}{l}832 \pm 34 \\
831 \pm 27\end{array}$ & $\begin{array}{l}857 \pm 26 \\
845 \pm 25\end{array}$ & $\begin{array}{l}886 \pm 22 \\
875 \pm 23\end{array}$ & $\begin{array}{l}872 \pm 24 \\
857 \pm 25\end{array}$ \\
\hline $\begin{array}{l}\text { 6-5 } \\
\text { Palatal side }\end{array}$ & $\begin{array}{c}\text { Non-cleft } \\
\text { Cleft }\end{array}$ & $\begin{array}{l}934 \pm 61 \\
913 \pm 40\end{array}$ & $\begin{array}{l}980 \pm 89 \\
951 \pm 37\end{array}$ & $\begin{array}{l}954 \pm 72 \\
927 \pm 35\end{array}$ & $\begin{array}{l}645 \pm 50 \\
634 \pm 50\end{array}$ \\
\hline $\begin{array}{c}\text { 7-6 } \\
\text { Palatal side }\end{array}$ & $\begin{array}{l}\text { Non-cleft } \\
\text { Cleft }\end{array}$ & $\begin{array}{l}899 \pm 39 \\
877 \pm 59\end{array}$ & $\begin{array}{l}934 \pm 47 \\
919 \pm 43\end{array}$ & $\begin{array}{l}880 \pm 37 \\
868 \pm 39\end{array}$ & $\begin{array}{l}542 \pm 57 \\
535 \pm 50\end{array}$ \\
\hline $\begin{array}{c}6-5 \\
\text { Buccal side }\end{array}$ & $\begin{array}{c}\text { Non-cleft } \\
\text { Cleft }\end{array}$ & $\begin{array}{l}825 \pm 42 \\
814 \pm 43\end{array}$ & $\begin{array}{l}846 \pm 38 \\
838 \pm 35\end{array}$ & $\begin{array}{l}870 \pm 41 \\
855 \pm 42\end{array}$ & $\begin{array}{l}643 \pm 47 \\
626 \pm 46\end{array}$ \\
\hline $\begin{array}{c}\text { 7-6 } \\
\text { Buccal side }\end{array}$ & $\begin{array}{c}\text { Non-cleft } \\
\text { Cleft }\end{array}$ & $\begin{array}{c}770 \pm 82 * * \\
721 \pm 63\end{array}$ & $\begin{array}{l}671 \pm 90 \\
660 \pm 88\end{array}$ & $\begin{array}{l}773 \pm 79 \\
759 \pm 77\end{array}$ & $\begin{array}{l}406 \pm 81 \\
397 \pm 79\end{array}$ \\
\hline Tuber & $\begin{array}{c}\text { Non-cleft } \\
\text { Cleft }\end{array}$ & $\begin{array}{l}650 \pm 125 \\
643 \pm 107\end{array}$ & $\begin{array}{l}566 \pm 129 \\
539 \pm 105\end{array}$ & $\begin{array}{l}408 \pm 98 \\
407 \pm 64\end{array}$ & $\begin{array}{l}265 \pm 55 \\
259 \pm 29\end{array}$ \\
\hline
\end{tabular}

**P 01/0> *P 05/0>

logies, Ann Arbor, MI, USA). This software includes an application to outline the selected bone within a defined area and to provide the average BMD in HU. Using the Xoran Cat software, version 3.1.62 the slices were made in the alveolar bone height in the range of 2-5-8- to $11 \mathrm{~mm}$ from the alveolar crest to the basal bone in mesio distal slices and in buccolingual slices on the right and left sides of the maxillary arch. In other words, BMD was measured in 4 heights $(2-5-8-11 \mathrm{~mm})$ from the alveolar bone to the basal bone in mesio distal and bucco-lingual slices in the following areas. Figures 1 and 2 show the mesiodistal and bucco-lingual measurement respectively. Between the right and left centrals ( 1 and 1); between the central and lateral incisors ( 1 and 2); between cuspids and first premolars ( 3 and 4 ); between the first and second premolars ( 4 and 5 ); between the second premolar and first molar (5 and 6); between the first and second molars ( 6 and 7 ); the region distal to second molars (7D) and tuberosity for both sides of the upper jaw. These heights were also measured on the palatal and buccal sides in mesio-distal slice only in the posterior region between the second premolar and first molar (5 and 6); between the first and second molars (6 and 7). Mean and standard deviations of BMD were measured for heights of 2-5-8 and $11 \mathrm{~mm}$ in cleft and non-cleft patients. T-test was used to analyze the bone density values between the cleft and noncleft. SPSS 18.0 (SPSS, Inc, Chicago, IL, USA) was used for statistical analysis. The differences were considered statistically significant with the $p<0.05$.

\section{Results}

The highest alveolar BMD in the mesio distal slice was $1004 \pm 6 \mathrm{HU}$ between the right and left centrals in the upper jaw in height of $11 \mathrm{~mm}$ in non-cleft patients. The least amount of alveolar BMD in the mesio-distal slice was $259 \pm 29 \mathrm{HU}$ in the tuberosity in height of 11 $\mathrm{mm}$ in cleft patients. The highest amount of BMD in the posterior region found was $980 \pm 89 \mathrm{HU}$ which was between the second premolar and the first molar in a depth of $5 \mathrm{~mm}$ from the mesio-distal view in non-cleft patients and it was $927 \pm 35 \mathrm{HU}$ in height of $8 \mathrm{~mm}$ in the same slice in cleft patients. The highest amount of BMD in the palatal side was $980 \pm 89 \mathrm{HU}$ in $5 \mathrm{~mm}$ from alveolar crest in non-clefts patients and the lowest one was $626 \pm 46 \mathrm{HU}$ in the buccal side in $11 \mathrm{~mm}$ from alveolar crest in clefts samples. Table 1 
Table 2. BMD in Hounsfield units (HU) from the bucco-palatal slice in the maxillary arch between teeth and tuberosity.

\begin{tabular}{|c|c|c|c|c|c|}
\hline & Bucco-palatal slice & $\mathbf{2} \mathbf{~ m m}$ & $\mathbf{5 m m}$ & $\mathbf{8 m m}$ & $\mathbf{1 1} \mathbf{m m}$ \\
\hline \multirow{2}{*}{ Region } & Group & Mean \pm SD & Mean \pm SD & Mean \pm SD & Mean \pm SD \\
\hline $\mathbf{1 - 1}$ & Non-cleft & $615 \pm 5^{* *}$ & $683 \pm 4^{* *}$ & $783 \pm 6^{* *}$ & $1639 \pm 11^{* *}$ \\
& Cleft & $607 \pm 5$ & $671 \pm 6$ & $772 \pm 6$ & $1582 \pm 26$ \\
\hline $\mathbf{2 - 1}$ & Non-cleft & $684 \pm 4^{* *}$ & $764 \pm 6^{* *}$ & $845 \pm 4^{* *}$ & $1447 \pm 10^{* *}$ \\
& Cleft & $673 \pm 7$ & $753 \pm 9$ & $836 \pm 6$ & $1438 \pm 10$ \\
\hline $\mathbf{3 - 2}$ & Non-cleft & $756 \pm 6^{* *}$ & $848 \pm 18^{* *}$ & $903 \pm 6^{* *}$ & $1257 \pm 10^{* *}$ \\
& Cleft & $744 \pm 7$ & $837 \pm 6$ & $894 \pm 6$ & $1248 \pm 10$ \\
\hline \multirow{2}{*}{$\mathbf{4 - 3}$} & Non-cleft & $825 \pm 5^{* *}$ & $924 \pm 5^{* *}$ & $963 \pm 4^{* *}$ & $1064 \pm 4^{* *}$ \\
& Cleft & $819 \pm 7$ & $917 \pm 7$ & $949 \pm 8$ & $1051 \pm 8$ \\
\hline $\mathbf{5 - 4}$ & Non-cleft & $934 \pm 6^{* *}$ & $993 \pm 4^{* *}$ & $1008 \pm 9^{* *}$ & $830 \pm 20$ \\
& Cleft & $921 \pm 7$ & $981 \pm 8$ & $1001 \pm 9$ & $822 \pm 19$ \\
\hline $\mathbf{6 - 5}$ & Non-cleft & $1078 \pm 18^{* *}$ & $1159 \pm 21^{* *}$ & $1030 \pm 9^{* *}$ & $674 \pm 105$ \\
& Cleft & $1064 \pm 19$ & $1146 \pm 20$ & $1018 \pm 9$ & $661 \pm 104$ \\
\hline $\mathbf{7 - 6}$ & Non-cleft & $1332 \pm 43$ & $1439 \pm 45$ & $1254 \pm 24^{* *}$ & $643 \pm 22^{*}$ \\
& Cleft & $1331 \pm 44$ & $1427 \pm 45$ & $1209 \pm 31$ & $631 \pm 19$ \\
\hline Tuber & Non-cleft & $833 \pm 34$ & $839 \pm 26$ & $365 \pm 19 *$ & $262 \pm 19 *$ \\
& Cleft & $822 \pm 32$ & $750 \pm 25$ & $354 \pm 17$ & $251 \pm 19$ \\
\hline
\end{tabular}

** $\mathrm{P} 01 / 0>\quad * \mathrm{P} 05 / 0>$

shows the means, standard deviations between the assessed areas on cleft and non-cleft patients in mesio-distal slices. The BMD of the anterior region of the maxilla in non-cleft patients was statistically higher than the cleft samples in the bucco-lingual slices in all areas. In non-cleft patients, the highest amount of BMD found was $1639 \pm 11 \mathrm{HU}$ between the centrals in height of $11 \mathrm{~mm}$ in the bucco-lingual slices in noncleft patients. The highest amount of BMD in the posterior region was found between the first and second molars in a depth of $5 \mathrm{~mm}$ from the bucco-lingual view in both cleft and non-cleft patients which was $1439 \pm 45 \mathrm{HU}$ and $1427 \pm 45 \mathrm{HU}$ respectively. There was no significant difference between the 2 groups in this area. The least amount of BMD found was $251 \pm 19 \mathrm{HU}$ in tuberosity in height of $11 \mathrm{~mm}$ in the bucco-lingual slice of cleft patients. Table 2 shows the values obtained for the means, standard deviations between the assessed areas on cleft and non-cleft patients in bucco-lingual slices.

\section{Discussion}

The result of this research can be used as additional information to select the most suitable area for anchorage devices such as mini- implants. These findings suggest that the best quality of alveolar bone density for mini implant installation from the mesiodistal view, may be in the posterior area between the second premolar and first molar in depth of $5 \mathrm{~mm}$ from the crest of the alveolar bone and also in the bucco-lingual slide, may be between the first and second molars in a depth of $5 \mathrm{~mm}$ from the crest of alveolar bone in cleft and non-cleft patients. The insertion of mini-implants in this area, considering only the highest BMD as a factor for success, would be more interesting. But one must keep in mind that this does not always occur, because other factors may contribute to loosening the mini-implants. For mini implant installation there must be adequate cortical bone thickness and also high BMD. It is considered that BMD is a key factor for the stability of mini-implants as anchorage. BMD should be such so as to favor the mechanical retention of the mini implant in a predetermined position. There are many factors for losing mini-implants as anchorage and one of these factors is poor bone density [12-15]. BMD has an important role in a successful implant. Areas of lesser bone quality have exhibited weaker stability and higher failure rates of dental implants $[16,17]$. The data which one obtained from this study will serve as guidelines for choosing the best quality of alveolar BMD for the placement of mini implants or dental implants. There was a progressive increase in BMD from cleft to non-cleft patients in all areas. This study showed that the maxillary tuberosity area had a lower BMD and also showed that BMD was greater on the palatal side than the buccal side between second premolars and the first \& second molars in both 
groups. Due to this fact anchorage devices can be applied on the palatal side. On the other hand, with respect to the aesthetic concerns of the device, and for greater mechanical control, mini implants can be inserted in the lingual side[18]. BMD can be measured in $\mathrm{HU}$ by $\mathrm{CT}$ and $\mathrm{CBCT}$ [8]. With $\mathrm{CT}$, BMD values are presented in Hounsfield Unit (HU) based on density of air $(-1,000 \mathrm{HU})$ and pure water $(0 \mathrm{HU})$.The density of cortical bone ranges from $\pm 1,000$ to $\pm 1,600 \mathrm{HU}$ values [19]. Turkyilmaz et al [20] determined that BMD ranged from 278 to $1,227 \mathrm{HU}$ in the jaws, with a mean of $751 \mathrm{HU}$. According to Turkyilmaz et al, the variability of the different amount of DBM in the literature is due to the effect of variables such as age and sex. BMD varies according the regions of the jaws and may be affected by many factors including osteoporosis, existence or absence of cleft [21-22].

Because of the high dosage of $\mathrm{CT}$ and lower dose of radiation exposure of $C B C T$, recently $C B C T$ has been widely used for craniofacial imaging [23].

Pripatnanont et al [24] found that the mean BMD after grafting in the cleft site was $426.1 \pm 120.1 \mathrm{HU}$ which was statistically lower than that in the noncleft site with the mean value of $543.9 \pm 120.2 \mathrm{HU}$. Regarding the different types of secondary alveolar bone grafting in patients with cleft lip and palate, Scalzone et al [25] in a systematic review found that the autologous bone and the rh-BMP2 graft showed a similar effectiveness in maxillary alveolar reconstruction assessing bone graft volume and height, although the rh-BMP2 grafta relative shorter shelf life. The use of BMD using CBCT required high stability and reliability of gray values and a consistent correlation between quantitative gray values and density. Various limitations are associated with the use of Hounsfield unit values in CBCT. These issues relate to the limited-field of CBCT geometry, basic radiation physics principles and the assumptions

\section{References}

1. Celenk C, Celenk P. Relationship of mandibular and cervical vertebral bone density using computed tomography. Dentomaxillofac Radiol. 2008;37(1):47-51.

[CrossRef] [PubMed] Google Scholar Scopus

2. Nackaerts $O$, Jacobs $R$, Horner $K$, et al. Bone density measurements in intra-oral radiographs. Clin Oral Investig. 2007;11(3):225-229.

[Full text links] [CrossRef] [PubMed] Google Scholar Scopus

3. Marquezan M, Lau TC, Mattos CT, et al. Bone mineral density: methods of measurement and its influence on primary stability of miniscrews. Angle Orthod. 2012;82(1):62-66. [Full text links] [CrossRef] [PubMed] Google Scholar Scopus

4. Aranyarachkul P, Caruso J, Gantes B, et al. Bone density assessments of dental implant sites: 2. Quantitative conebeam computerized tomography. Int J Oral Maxillofac Implants. 2005;20(3):416-424.

[PubMed] Google Scholar Scopus

5. Park HS, Lee YJ, Jeong SH, Kwon TG. Density of the alveolar and basal bones of the maxilla and the mandible. Am J Orthod Dentofacial Orthop. 2008;133(1):30-37. [Full text links] [CrossRef] [PubMed] Google Scholar Scopus

6. Choi JH, Park $\mathrm{CH}, \mathrm{Yi}$ SW, et al. Bone density measurement in interdental areas with simulated placement of orthodontic miniscrew implants. Am J Orthod Dentofacial Orthop. 2009;136(6):766. e1-e12; discussion 766-777.

[Full text links] [CrossRef] [PubMed] Google Scholar Scopus and limitations of currently used reconstruction algorithms [25].

\section{Conclusions}

BMD in non-cleft patients was higher than in cleft patients in all areas; however, the mean BMD in noncleft patients was significantly greater than in cleft patients from the upper left to the right canines in all areas in the medio-distal slice. Significantly higher BMD was found in the labial cortical plate between the centrals on the mesio distal direction in depth of $11 \mathrm{~mm}$ from the alveolar crest in cleft and non-cleft patients. The highest amount of BMD was found between the first and second molars on the bucco palatal area $5 \mathrm{~mm}$ from the alveolar crest in cleft and non-cleft patients and the differences between them were not statistically significant. The maxillary tuberosity showed the lowest BMD.

The amount of BMD was higher in the palatal side than the buccal side both in cleft and non-cleft patients between the second premolar and the first \& second molars.

\section{Author Contributions}

MSN: responsible for study design, administration, data interpretation, recruitment, statistical analysis, literature review. ART: responsible for data interpretation, critical revision and final approval of the article. AJ: responsible for the study concept, study design, data interpretation, critical revision, writing and revising the report and final approval of the article. $L N$ : responsible for the literature review. AAK: responsible for data gathering, LP: responsible for drafting, data interpretation, critical revision and final approval of the article.

\section{Acknowledgment}

There is no conflict of interest.

7. Miracle AC, Mukherji SK. Conebeam CT of the head and neck, part 1: physical principles. AJNR Am J Neuroradiol. 2009;30(6):1088-1095.

[Full text links] [CrossRef] [PubMed] Google Scholar Scopus

8. Lee S, Gantes B, Riggs M, Crigger M. Bone density assessments of dental implant sites: 3. Bone quality evaluation during osteotomy and implant placement. Int J Oral Maxillofac Implants. 2007;22(2):208-212. [PubMed] Google Scholar Scopus

9. Gonzalez-Garcia $\mathrm{R}$, Monje $\mathrm{F}$. The reliability of cone-beam computed tomography to assess bone density at dental implant recipient sites: a histomorphometric analysis by micro-CT. Clin Oral Implants Res. 2013;24(8):871-879.

[Full text links] [CrossRef] [PubMed] Google Scholar Scopus

10. Jain S, Choudhary K, Nagi R, et al. New evolution of conebeam computed tomography in dentistry: combining digital technologies. Imaging Sci Dent. 2019;49(3):179-190. [Full text links] [Free PMC Article] [CrossRef] [PubMed] Google Scholar

11. Katsumata A, Hirukawa A, Okumura $S$, et al. Effects of image artifacts on gray-value density in limited-volume cone-beam computerized tomography. Oral Surg Oral Med Oral Pathol Oral Radiol Endod. 2007;104(6):829-836.

[Full text links] [CrossRef] [PubMed] Google Scholar Scopus

12. Bergkvist G, Koh KJ, Sahlholm S, et al. Bone density at implant sites and its relationship to assessment of bone quality 
and treatment outcome. Int J Oral Maxillofac Implants. 2010;25(2):321-328.

[PubMed] Google Scholar Scopus

13. Perillo L, Jamilian A, Shafieyoon A, et al. Finite element analysis of miniscrew placement in mandibular alveolar bone with varied angulations. Eur J Orthod. 2015;37(1):56-59. [Full text links] [CrossRef] [PubMed] Google Scholar Scopus

14. Cozzani M, Sadri D, Nucci L, et al. The effect of Alexander, Gianelly, Roth, and MBT bracket systems on anterior retraction: a 3-dimensional finite element study. Clin Oral Investig. 2019 Jul 28

[Full text links] [CrossRef] [PubMed] Google Scholar Scopus

15. Cozzani M, Azizi A, Eslami S, et al. 3-dimensional finite element analysis of the outcomes of Alexander, Gianelly, Roth and MBT bracket prescription. Int Orthod. 2019;17(1):45-52. [Full text links] [CrossRef] [PubMed] Google Scholar Scopus

16. Merheb J, Van Assche N, Coucke W, et al. Relationship between cortical bone thickness or computerized tomography-derived bone density values and implant stability. Clin Oral Implants Res. 2010;21(6):612-617. [Full text links] [CrossRef] [PubMed] Google Scholar Scopus

17. Akdeniz BG, Oksan T, Kovanlikaya I, Genc I. Evaluation of bone height and bone density by computed tomography and panoramic radiography for implant recipient sites. J Oral Implantol. 2000;26(2):114-119.

[Full text links] [CrossRef] [PubMed] Google Scholar Scopus

18. Monnerat C, Restle L, Mucha JN. Tomographic mapping of mandibular interradicular spaces for placement of orthodontic mini-implants. Am J Orthod Dentofacial Orthop. 2009;135(4):428. e1-e9; discussion 428-429.

[Full text links] [CrossRef] [PubMed] Google Scholar Scopus

19. Norton MR, Gamble C. Bone classification: an objective scale of bone density using the computerized tomography scan. Clin Oral Implants Res. 2001;12(1):79-84.

[Full text links] [CrossRef] [PubMed] Google Scholar Scopus
20. Turkyilmaz I, Tözüm TF, Tumer C, Ozbek EN. Assessment of correlation between computerized tomography values of the bone, and maximum torque and resonance frequency values at dental implant placement. J Oral Rehabil. 2006;33(12):881-888. [Full text links] [CrossRef] [PubMed] Google Scholar Scopus

21. Lindh $\mathrm{C}$, Obrant $\mathrm{K}$, Petersson A. Maxillary bone mineral density and its relationship to the bone mineral density of the lumbar spine and hip. Oral Surg Oral Med Oral Pathol Oral Radiol Endod. 2004;98(1):102-109.

[Full text links] [CrossRef] [PubMed] Google Scholar Scopus

22. Benlidayi ME, Tatli U, Kurkcu M, et al. Comparison of bovinederived hydroxyapatite and autogenous bone for secondary alveolar bone grafting in patients with alveolar clefts. J Oral Maxillofac Surg. 2012;70(1):e95-e102.

[Full text links] [CrossRef] [PubMed] Google Scholar Scopus

23. Mah JK, Danforth RA, Bumann A, Hatcher D. Radiation absorbed in maxillofacial imaging with a new dental computed tomography device. Oral Surg Oral Med Oral Pathol Oral Radiol Endod. 2003;96(4):508-513.

[Full text links] [CrossRef] [PubMed] Google Scholar Scopus

24. Pripatnanont $\mathrm{P}$, Nuntanaranont $\mathrm{T}$, Vongvatcharanon $\mathrm{S}$ Proportion of deproteinized bovine bone and autogenous bone affects bone formation in the treatment of calvarial defects in rabbits. Int J Oral Maxillofac Surg. 2009;38(4):356362.

[Full text links] [CrossRef] [PubMed] Google Scholar Scopus

25. Pauwels R, Jacobs R, Singer SR, Mupparapu M. CBCT-based bone quality assessment: are Hounsfield units applicable? Dentomaxillofac Radiol. 2015;44(1):20140238. [Full text links] [Free PMC Article] [CrossRef] [PubMed] Google Scholar
Mohammad Sadegh NAZARI

Postgraduate Student

Department of Orthodontics

School of Dentistry

Mashhad University of Medical Sciences, Mashhad, Iran

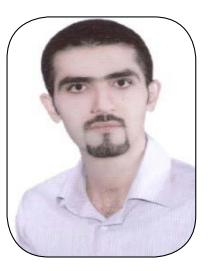

Maohammad Sadegh Nazari graduated from the Tehran Azad University of Dental School in 2017 and as a resident of orthodontics in 2018 at the Mashhad University of Medical Science. He became a top Iranian student researcher in 2016 and a national student in 2016. He has published 9 articles. He has participated in various conferences and congresses and has had several oral presentation and posters. His scientific interests are focused on orthognathic surgery patients. 


\section{Ouestions}

\section{What is the amount of bone tissue?}

Da. Hounsfield unit;

ab. Bone mineral density (BMD);

ac. Bone resorption;

$\square$ d. Bone remodeling.

2. Which one is used to evaluate anatomic structures and thr direct measurement of mineralized tissue before dental implant?

Da. CBCT;

ab. $\mathrm{HU}$;

口c. MRI;

घd. CT.

3. What is the highest alveolar bone density in the mesio distal between ... in the upper jaw in height of ... mm in ... patient?

$\square$ a. Right and left centrals, 8, non-cleft;

ab. Central and lateral, 11, non-cleft;

口c. Right and left centrals, 11, non-cleft;

ud. Central and lateral, 8, non-cleft.

\section{Which is the highest amount of bone density in the posterior region?}

$\square$ a. First and second molars;

ab. Second premolar and first molar;

$\square$ c. First and second premolars;

ad. Second and third molars.
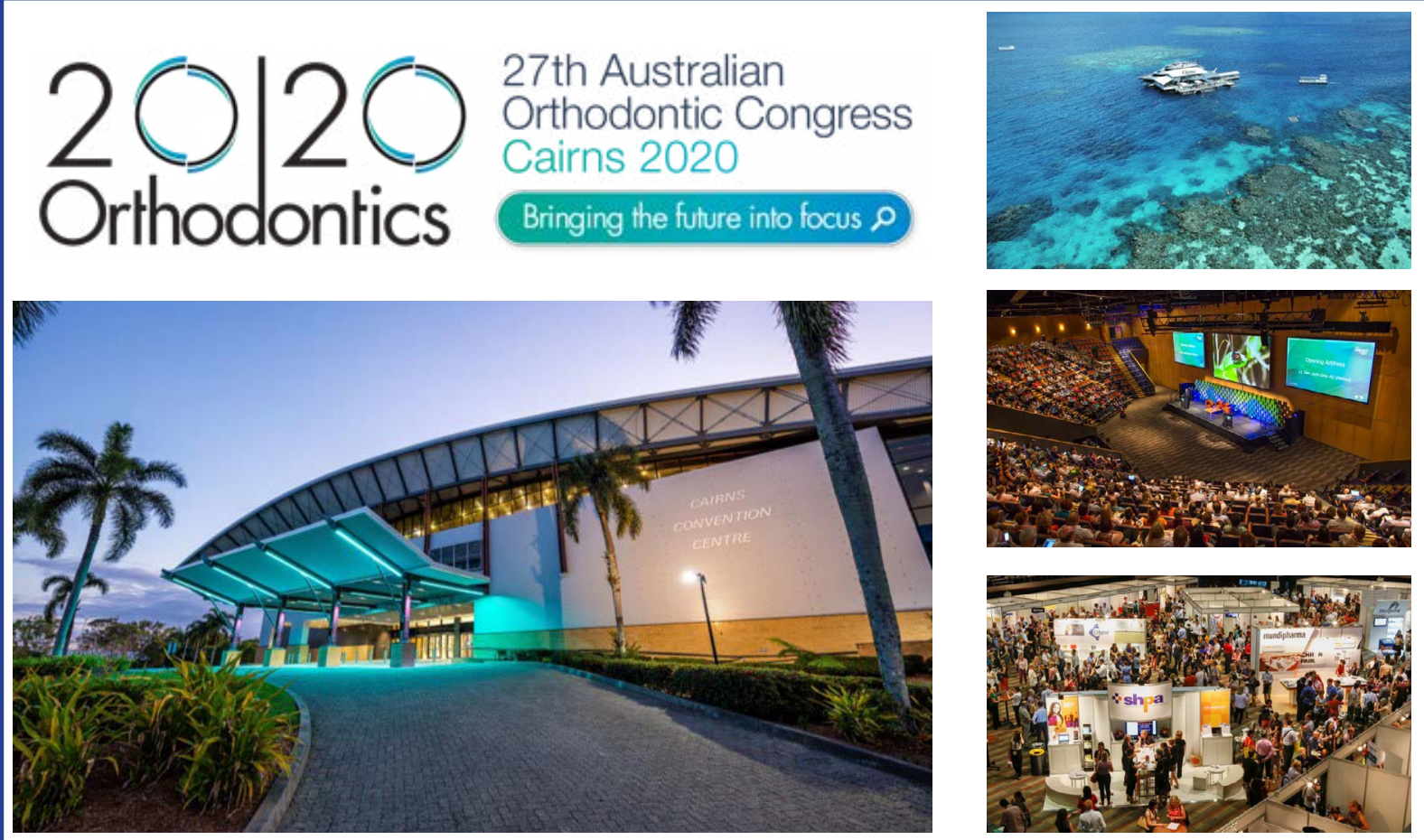

19 - 20 March 2020

Cairns Convention Centre www.aso2020cairns.com.au 